\title{
ETHNOPHARMACOLOGICAL EVALUATION OF SELECTED EAST KALIMANTAN FLORA FOR DIABETES THERAPY: THE ISOLATION OF LUPANE TRITERPENOIDS AS $\alpha$-GLUCOSIDASE INHIBITORS FROM Ceriops tagal (PERR) C.B.ROBB
}

\author{
R. Ramadhan 1,2,", P. Phuwapraisirisan ${ }^{3}$, I.W. Kusuma ${ }^{4}$ and R. Amirta ${ }^{4}$ \\ ${ }^{1}$ Department of Chemistry, Faculty of Science and Technology/Airlangga University, \\ Surabaya-60115, (East Jawa) Indonesia \\ ${ }^{2}$ Division of Exploration and Synthesis of Bioactive Compounds, Research Center for Bio- \\ Molecule Engineering/Airlangga University, Surabaya-60115, (East Jawa) Indonesia \\ ${ }^{3}$ Center of Excellence in Natural Products Chemistry, Faculty of Science/Chulalongkorn \\ University, Bangkok-10330, (Bangkok) Thailand \\ ${ }^{4}$ Forest Products Chemistry and Renewable Energy Laboratory, Faculty of \\ Forestry/Mulawarman University, Samarinda-75242, (East Kalimantan) Indonesia \\ *E-mail: rico.ramadhan@fst.unair.ac.id
}

\begin{abstract}
The current study evaluated the antidiabetic activity of particular East Kalimantan plants that have long been used by Dayak people for diabetes therapy and identified the active compounds in these plants. However, the antidiabetic activity of the indigenous plants has not been systematically investigated. Phytochemical analysis of six selected East Kalimantan plant extracts was conducted to investigate their: (1) antidiabetic activities (via $\alpha$-glucosidase inhibition bioassays), (2) DPPH radical scavenging activities, and (3) total antioxidant capacities. Additionally, the mechanisms underlying the inhibitory effects of the isolated compounds were determined by Lineweaver-Burk plots. The extracts showed $\alpha$-glucosidase inhibitory activities with $\mathrm{IC}_{50}$ values ranging from 0.07 to 8.09 $\mathrm{mg} / \mathrm{mL}$. Ceriops tagal exhibited the highest DPPH radical scavenging activity ( $\mathrm{IC}_{50} 26.24 \mu \mathrm{g} / \mathrm{mL}$ ), as well as the highest total antioxidant capacity $(215.16 \pm 0.02 \mathrm{mgGAE} / \mathrm{g})$. Bioassay-guided isolation of $C$. tagal, which was the plant with the most significant apparent potential, yielded three triterpenoids: lupeol (1), betulone (2), and betulin (3). Of the isolated compounds, 3 exhibited the highest inhibition with $\mathrm{IC}_{50}$ value of $18.87 \mu \mathrm{M}$. Furthermore, all isolated triterpenoids showed noncompetitive inhibition action. The systematic screening approaches were successfully applied to identify antidiabetic agents from East Kalimantan plants.

Keywords: Antidiabetes, Antioxidant, Ceriops tagal, Ethnopharmacology, East Kalimantan.
\end{abstract}

(C) RASĀYAN. All rights reserved

\section{INTRODUCTION}

Diabetes mellitus (DM) is a chronic and complex disorder of metabolic ailment caused by hyperglycemia, subsequent from lacking pancreatic insulin secretion, with the change of insulin action that can develop complications in diabetes. ${ }^{1-3}$ The onset of diabetes mellitus is attributed to several factors including persistent hyperglycemia toxicity and oxidative stress. ${ }^{4}$ Recently, studies have shown that oxidative stress is involved in the development of diabetic complications by impairing the oxidation-reduction a system, which leads to $\beta$-cell failure and insulin resistance. ${ }^{5}$ Current clinical therapies are based on the control of postprandial hyperglycemia by the $\alpha$-glucosidase as a target. Among them, the most effective pharmacological $\alpha$-glucosidase inhibitors are acarbose, miglitol and voglibose ${ }^{6}$ However, consumption of those synthetic drugs should be limited because potentially produce various side effects such as Rasayan J. Chem., 13(3), 1727-1734(2020) http://dx.doi.org/10.31788/RJC.2020.1335559 
RASĀYAN J. Chem.

Vol. 13 | No. 3 |1727-1734| July - September | 2020

abdominal cramp, vomiting and diarrhea. ${ }^{7,8}$ Several studies have been carried out to investigate natural products such as active natural secondary metabolites or crude extracts that have potency as an inhibitor of $\alpha$-glucosidase activity. Notably, recent evidence has shown that natural antioxidants are possibly useful in decreasing oxidative damage and reducing the occurrence of diabetes complications. ${ }^{9}$ Accordingly, the current study is designated to screen for plants that show promise in the prevention of diabetes mellitus and reduction of complications.

In terms of biodiversity, East Kalimantan is covered by the largest forest area in Indonesia and is comprised of a variety of forest types, including mangrove, coastal, swamp, forest with limestone, and evergreen tropical. It is believed to be an area that still harbors numerous unknown and endemic species of flora that have not yet been described. ${ }^{10}$ Although, botanical surveys of East Kalimantan flora are conducted annually, only approximately $10 \%$ of the identified plants have been further investigated for potential applications in natural medicines. Besides, biological and chemical screenings of all collected plants are tedious, time-consuming, and perhaps low-hit-target. These problems could be addressed by taking ethnopharmacology into account, which is considered as scientific evidence observed by local people who utilize medicinal plants for a particular therapy. Ethnopharmacology is practiced by local people in a variety of locations around the world, including East Kalimantan. ${ }^{11,12}$ Traditionally, local people in the East Kalimantan region (called "Dayak" communities) have known to share [based on heredity or generation by generation] important information about plants that have religious, medicinal, and or economic importance in their communities. ${ }^{13}$ The approach of using ethnopharmacologically bases in plant selection strategies is valid toward the identification of bioactive compounds of plants for indepth examination. ${ }^{14}$ Even though many studies have reported the use of East Kalimantan plants to cure several illnesses, there are only a few studies published on the treatment of diabetes mellitus by such remedies. ${ }^{15}$ Therefore, inspired by ethnopharmacological records for diabetes therapy, we selected six plants and evaluated their potency as antidiabetic and antioxidant. Then, we further studied the plant that displayed the most significant anti-diabetic potential, to identify its active components and determine their mechanisms of inhibition.

\section{Plant Material and Preparation of Extracts}

\section{EXPERIMENTAL}

Plants (Table-1) were collected from their natural habitat from March to April 2013 in the rain forest of East Kalimantan, Indonesia. Plant specimens were then kept in the Forest Product Chemistry and Renewable Energy Laboratory, Mulawarman University. The plants were air-dried at ambient temperature, ground into powder, and extracted using methanol for 24 hours. The crude plant materials extract obtained were pooled, filtered, and evaporated with a rotary evaporator. The extracts were kept in the cold before further experiments.

Table-1: Selected Plants From East Kalimantan for Diabetes Therapy

\begin{tabular}{c|c|c|c}
\hline Plant Materials & Voucher Specimens & Local Names & Part \\
\hline Leucaena leucocephala & KK-1305-LA001 & Lamtoro/petai cina & Seeds \\
\hline Swietenia macrophylla King & KK-1305-MA001 & Mahoni & Seeds \\
\hline Pycnarrhena tumefacta & KK-1305-BK001 & Apa'Bekai & Leaf \\
\hline Luvunga eleutherandra Dalz & KK-1305-SE001 & Seluang Belum & Roots \\
\hline Cresentia cujete & KK-1305-BR001 & Berenuk & Leaf \\
\hline Ceriops tagal (Perr.) C.B. Rob & KK-1305-TI001 & Tingi & Leaf \\
\hline
\end{tabular}

\section{Inhibition Assay for $\alpha$-Glucosidase}

The $\alpha$-glucosidase inhibition assay was accomplished according to the previous report. ${ }^{16}$ In 96 well plates, $10 \mu \mathrm{L}$ of crude extract and isolated compounds were pre-incubated with enzyme for $10 \mathrm{~min}\left(37^{\circ} \mathrm{C}\right)$, followed by the addition of $50 \mu \mathrm{L}$ of the substrate solution ( $p$-NPG), then reaction mixture was incubated for $20 \mathrm{~min}$. The reaction mixture was terminated by adding $\mathrm{Na}_{2} \mathrm{CO}_{3} 1 \mathrm{M}$, and it was quantified by measurement of $405 \mathrm{~nm}$ absorbance. The $\alpha$-glucosidase inhibition percentage was evaluated as follows: $\%$ Inhibition $=\left[\left(\mathrm{A}_{0}-\mathrm{A}_{1}\right) / \mathrm{A}_{0}\right] \times 100$, where $\mathrm{A}_{0}$ was the absorbance without the sample, and $\mathrm{A}_{1}$ was the absorbance with the sample. The $\mathrm{IC}_{50}$ value was determined from a plot of $\%$ inhibition versus the final concentration of reaction. 
RASĀYAN J. Chem.

Vol. 13 | No. 3 |1727-1734| July - September | 2020

Also, the inhibition toward rat intestinal (maltase and sucrose) was measured according to a method previously reported by our group. ${ }^{17}$ To each well, $10 \mu \mathrm{L}$ samples with various concentrations were added together with $10 \mu \mathrm{L}$ phosphate buffer, $20 \mu \mathrm{L}$ of maltose $10 \mathrm{mM}$ and sucrose $100 \mathrm{mM}$, respectively. Then, the reaction system was added with $20 \mu \mathrm{L}$ of enzyme solution and $80 \mu \mathrm{L}$ glucose kit was then incubated for either $10 \mathrm{~min}$ or $40 \mathrm{~min}$ for maltose and sucrose, respectively. Enzymatic activity was quantified spectrophotometrically at $503 \mathrm{~nm}$. The $\alpha$-glucosidase inhibition percentage and $\mathrm{IC}_{50}$ value were calculated by the same method as the baker's yeast. All measurements were done in triplicate.

\section{Quantitative Phytochemical Analysis and Antioxidant Activity Total Antioxidant Capacity (TAC)}

The total antioxidant content of each extract was evaluated by using the previous protocol with slight modification. ${ }^{18}$ Total antioxidant values are expressed in terms of gallic acid equivalents (GAE) per gram of extracts.

\section{Total Phenolic Content (TPC)}

We determined total phenolic content by applying the Folin-Ciocalteau method with slight modification. ${ }^{19}$ The total phenolic content was determined by using a spectrophotometer at $750 \mathrm{~nm}$. Total phenolic content was expressed as a gallic acid equivalent (GAE). All measurements were done in triplicate.

\section{Total Flavonoids Content (TFC)}

The total flavonoid content of samples was determined by employing the previous procedure. ${ }^{20}$ The absorbance was determined at $500 \mathrm{~nm}$, and all experiments were performed in triplicate. Total flavonoids content is stated in terms of quercetin equivalents $(\mathrm{QE})$ per gram plant extracts.

\section{Free Radical Inhibitory Activity DPPH}

The antioxidant activity of samples was evaluated by free radical 2,2'-diphenyl-1-picrylhydrazyl (DPPH) using a previously published method with slight modification. ${ }^{21}$ In brief, $100 \mu \mathrm{L}$ of $0.10 \mathrm{mM}$ DPPH methanolic solution was mixed with samples with various concentrations. Thus, the reaction mixture was incubated for $20 \mathrm{~min}$ in the dark, and the absorbance was determined spectrophotometrically at 517 $\mathrm{nm}$. All experiments were done in triplicate.

\section{Isolation of Secondary Metabolites and Kinetic Studies}

The isolation of secondary metabolites was accomplished on silica gel 60 (70-230 mesh) or Sephadex LH-20 by column chromatography technic. In brief, the air-dried leaves $(58 \mathrm{~g})$ of C.tagal were soaked with $\mathrm{MeOH}$ for $48 \mathrm{~h}$, and the extract was concentrated by evaporation to yielded crude extract $(25 \mathrm{~g})$. The residue was partitioned with $n$-hexane to obtain $\mathrm{MeOH}$ and $n$-hexane extracts. The methanol extract (2.8 g) was chromatographed on quick column chromatography (QCC) and eluted with dichloromethane: $n$ hexane, which yielded seven fractions (A-G). Fraction C $(87 \mathrm{mg})$ was chromatographed and eluted using dichloromethane: $n$-hexane (1:1), which yielded lupeol $(1,60 \mathrm{mg})$. Fraction D (93 mg) was passed through a Sephadex LH-20 column in MeOH. Fraction D was further purified using Sephadex LH-20packed column and eluted with a mixture of 1:1:8 EtOAc-MeOH- $n$-hexane to give betulone $(2,7 \mathrm{mg})$. Fraction E (141 mg) was first passed through a Sephadex LH-20 column (MeOH elution) then through a silica gel column with elution using a 1:9 mixture of EtOAc: $n$-hexane to afford betulin $(3,19 \mathrm{mg})$. Isolated compounds were identified using ${ }^{1} \mathrm{H}$ and ${ }^{13} \mathrm{C}$ NMR spectroscopies and via comparison with those of previous studies. ${ }^{22}$ Also, the anti-diabetes activity of isolated compounds (1-3) was determined against $\alpha$-glucosidase (Baker's yeast and rat intestine). Furthermore, kinetic studies of isolated compounds (1-3) were investigated by Lineweaver-Burk plots. ${ }^{23}$

\section{RESULTS AND DISCUSSION}

\section{Inhibition Assay for a-Glucosidase}

We first investigated the extracts of selected plants for their $\alpha$-glucosidase inhibitory activities. The extracts exhibiting inhibitory activity against yeast $\alpha$-glucosidase, maltase, and sucrase with $\mathrm{IC}_{50}$ values in 
RASĀYAN J. Chem.

the ranges of $0.07-8.09,1.70-5.33$, and $3.02-21.80 \mathrm{mg} / \mathrm{mL}$, respectively were shown in Table-2. Of all extracts examined, the leaf extract of C.tagal consistently had the top inhibition against all target enzymes with $\mathrm{IC}_{50}$ values $(\mathrm{mg} / \mathrm{mL}$ ) of 0.07 (yeast $\alpha$-glucosidase), 1.70 (maltase) and 3.02 (sucrase), respectively. The potent inhibitory effect against yeast $\alpha$-glucosidase was strikingly evident because C.tagal extract showed 58-time more potency than Cresentia cujete, which was the second most potent extract $\left(\mathrm{IC}_{50} 4.08\right.$ $\mathrm{mg} / \mathrm{mL}$ ). However, the inhibitory potency of C.tagal was relatively less pronounced when tested against maltase and sucrase.

Table-2: $\alpha$-Glucosidase Inhibitory Effect of Selected Plants

\begin{tabular}{c|c|c|c}
\hline \multirow{2}{*}{ Plants } & \multicolumn{3}{|c}{$\mathrm{IC}_{50}$ values $(\mathrm{mg} / \mathrm{mL})^{*}$} \\
\cline { 2 - 4 } & Yeast & Maltase & Sucrase \\
\hline Leucaena leucocephala & $6.11 \pm 0.03$ & $1.88 \pm 0.95$ & $16.58 \pm 12.4$ \\
\hline Swietenia macrcophylla King & $8.09 \pm 0.48$ & $4.56 \pm 2.20$ & $5.88 \pm 4.47$ \\
\hline Pycnarrhena tumefacta & $5.33 \pm 0.57$ & $5.33 \pm 3.83$ & $8.72 \pm 4.16$ \\
\hline Luvunga eleutherandra Dalz & $5.87 \pm 0.73$ & $3.79 \pm 0.67$ & $21.80 \pm 10.4$ \\
\hline Crescentia cujete & $4.08 \pm 0.25$ & $2.95 \pm 0.71$ & $5.78 \pm 0.82$ \\
\hline Ceriops tagal (Perr.) C.B. Rob & $0.07 \pm 0.001$ & $1.70 \pm 0.55$ & $3.02 \pm 2.82$ \\
\hline
\end{tabular}

*Data shown as mean of triplicate experiments \pm SD. Acarbose was the standard positive control with $\mathrm{IC}_{50}$ values of $2.99 \pm 0.75 \mathrm{mg} / \mathrm{mL}$ (yeast glucosidase), $0.49 \pm 0.05 \mathrm{mg} / \mathrm{mL}$ (maltase) and $0.49 \pm 0.12 \mathrm{mg} / \mathrm{mL}$ (sucrase), respectively.

The bark extract of C.tagal (which grows in the Philippines) has previously been reported to exert an inhibitory effect against yeast $\alpha$-glucosidase. ${ }^{24}$ However, it has not yet been investigated to identify its active components or evaluate its antioxidant activity. The aforementioned results suggested that C.tagal should be further investigated to categorize the active constituents responsible for its antidiabetic activity and elucidate its inhibitory mechanisms.

\section{Quantitative Phytochemical Analysis and Antioxidant Activity}

The present study further elucidated the natures of the antioxidant activities of the selected plant extracts. The antioxidant activities were determined through measurements of total antioxidant capacity and DPPH radical scavenging (Table-3). According to the research findings, the C. tagal extract exhibited the highest total antioxidant capacity $(215.16 \pm 0.02 \mathrm{mgGAE} / \mathrm{g})$ and the most potent towards DPPH radical scavenging $\left(\mathrm{IC}_{50} 26.24 \mu \mathrm{g} / \mathrm{mL}\right)$.

Table-3: TPC, TFC, TAC and DPPH Radical Scavenging of Selected Plants

\begin{tabular}{c|c|c|c|c}
\hline Plants & $\begin{array}{c}\text { TAC } \\
\text { mgGAE/g Dry } \\
\text { Extract* }\end{array}$ & $\begin{array}{c}\text { DPPH } \\
\text { Scavenging } \\
\left(\mathrm{IC}_{50}\right) \mu \mathrm{g} / \mathrm{mL}^{*}\end{array}$ & $\begin{array}{c}\text { TPC } \\
\text { mgAE/g Dry } \\
\text { Extract* }\end{array}$ & $\begin{array}{c}\text { TFC } \\
\text { mgCE/g Dry } \\
\text { Extract* }\end{array}$ \\
\hline Leucaena leucocephala & $77.58 \pm 0.02$ & $88.92 \pm 3.19$ & $137.40 \pm 0.08$ & $16.70 \pm 0.02$ \\
\hline Swietenia macrcophylla King & $62.88 \pm 0.07$ & $31.76 \pm 10.4$ & $13.92 \pm 0.01$ & $1.32 \pm 0.004$ \\
\hline Pycnarrhena tumefacta & $77.71 \pm 0.01$ & $98.54 \pm 6.20$ & $26.40 \pm 0.01$ & $50.36 \pm 0.03$ \\
\hline Crescentia cujete & $152.21 \pm 0.01$ & $39.33 \pm 3.88$ & $105.92 \pm 0.01$ & $31.80 \pm 0.05$ \\
\hline Ceriops tagal (Perr.) C.B. Rob & $215.16 \pm 0.02$ & $26.24 \pm 2.89$ & $42.30 \pm 0.01$ & $137.53 \pm 0.03$ \\
\hline
\end{tabular}

* Data are shown as the mean of triplicate experiments \pm SD.

These results suggested that high antioxidant activity of the $C$. tagal extract is likely a consequence of its high flavonoid content $(137.53 \pm 0.03 \mathrm{mgCE} / \mathrm{g})$, which is comparable to that of $C$. cujete $(139.85 \pm 0.04$ $\mathrm{mgCE} / \mathrm{g})$. However, relatively moderate content of phenolics $(42.30 \pm 0.01 \mathrm{mgGAE} / \mathrm{g})$ suggested that other secondary metabolites present in $C$. tagal extract are also likely to contribute to antioxidant activity, in addition to flavonoids and phenolics. Phenolics and flavonoids are secondary metabolites that showed not only beneficial effects as natural antioxidants by their capability to inhibit free radicals but also their potency to inhibit the oxidative activity of the enzyme. ${ }^{25}$ On the other hand, a positive beneficial was found that the increase of antioxidants will reduce diabetes complications initiated by free radicals. 
RASĀYAN J. Chem.

Vol. 13 | No. 3 |1727-1734| July - September | 2020

Moreover, natural antioxidants may act as free radical inhibitors and anti-oxidative enzyme to prevent cell damage in biological systems. ${ }^{26}$

\section{Isolation of Secondary Metabolites and Kinetic Studies}

Based on the aforementioned results, $C$. tagal was selected for further investigation to isolate the bioactive compounds. Bioassay-guided isolation of the $\mathrm{MeOH}$ fraction from $C$. tagal leaves yielded lupeol (1), betulone (2) and betulin (3) (Fig.-1). The ${ }^{1} \mathrm{H}$ and ${ }^{13} \mathrm{C}$ NMR spectral data of isolated compounds (1-3) were in good agreement with those of previous studies. ${ }^{27-29}$ In Table-4, compounds 1-3 inhibited yeast $\alpha$-glucosidase with $\mathrm{IC}_{50}$ values in the range of $18.87-27.73 \mu \mathrm{M}$. Triterpenoids $\mathbf{1}-\mathbf{3}$ showed strikingly potent activity, compared with antidiabetic drug acarbose. Betulin (3) displayed approximately 5-fold more potent inhibition than acarbose.
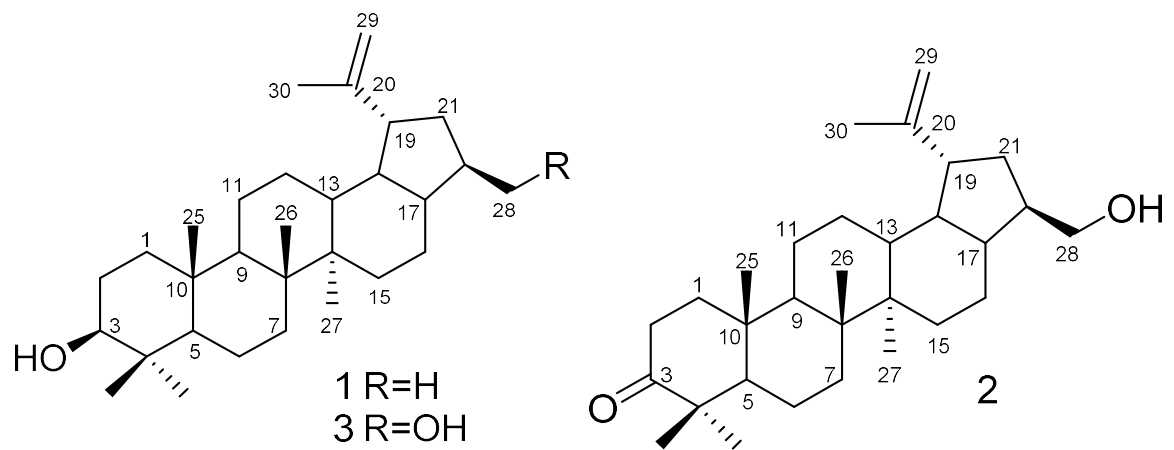

Fig.-1: Chemical Structures of Lupane Triterpenoids From Ceriops tagal (Perr.) C.B. Rob.

Table-4: $\alpha$-Glucosidase Inhibition of Isolated Compounds (1-3)

\begin{tabular}{c|c|c|c}
\hline \multirow{2}{*}{ Compounds } & \multicolumn{3}{|c}{$\mathrm{IC}_{50}(\mu \mathrm{M})^{*}$} \\
\cline { 2 - 4 } & \multirow{2}{*}{ Yeast } & \multicolumn{2}{|c}{ Rat Intestinal } \\
\cline { 2 - 4 } & & Maltase & Sucrase \\
\hline 1 & 23.90 & $\mathrm{NI}^{* *}$ & $1,052.66$ \\
\hline 2 & 27.73 & $\mathrm{NI}$ & $1,194.77$ \\
\hline 3 & 18.87 & $\mathrm{NI}$ & $1,186.75$ \\
\hline Acarbose & 103.0 & 2.1 & 26.0 \\
\hline
\end{tabular}

* All the assays were repeated two times

**No inhibition, inhibitory activities $<30 \%$ at $10 \mathrm{mg} / \mathrm{mL}$

Also, the inhibition of $\mathbf{1}$ and $\mathbf{2}$ was more slightly potent, more or less 4.3 and 3.7 folds than acarbose, respectively. On the other hand, 1-3 showed no inhibition toward rat intestinal maltase, whereas their inhibition against sucrase was weak. Inhibitory activities against yeast $\alpha$-glucosidase of lupeol (1), betulone (2) and betulin (3) were recently documented. Although lupeol (1) has been reported to function via non-competitive inhibitory mechanisms, the complete mechanism of betulone (2) and betulin (3) in inhibiting $\alpha$-glucosidase activity has not been fully understood.

Furthermore, we conducted kinetic studies on compounds 1-3 into the mechanisms underlying the inhibitory effects. Interestingly, the investigation by the Linewaver-Burk plots revealed $K_{\mathrm{m}}$ value constant and the increasing concentrations of inhibitors (1-3) followed by the decrease of $V_{\max }$ (Figs.-2 to -4). This manner indicated that the enzyme was inhibited by 1-3 in noncompetitive. Therefore, they can directly attach to the binding site of the enzyme to form an enzyme-inhibitor (EI) complex and simultaneously bind to an enzyme-substrate intermediate to generate an enzyme-substrate-inhibitor (ESI) complex (Fig.5). To subsequently examine the pathways in which $1-\mathbf{3}$ preferentially proceeded, we determined $K_{i}$ and $K_{i}^{\prime}$ (Table-5). The slightly $K_{i}^{\prime}$ values of $\mathbf{1}$ and $\mathbf{3}$ suggested that these inhibitors dominantly bound to enzyme-substrate intermediate rather than directly bound to enzyme; however, the binding preference observed for $\mathbf{2}$ was opposite. 
RASĀYAN J. Chem.

Vol. 13 | No. 3 |1727-1734| July - September | 2020
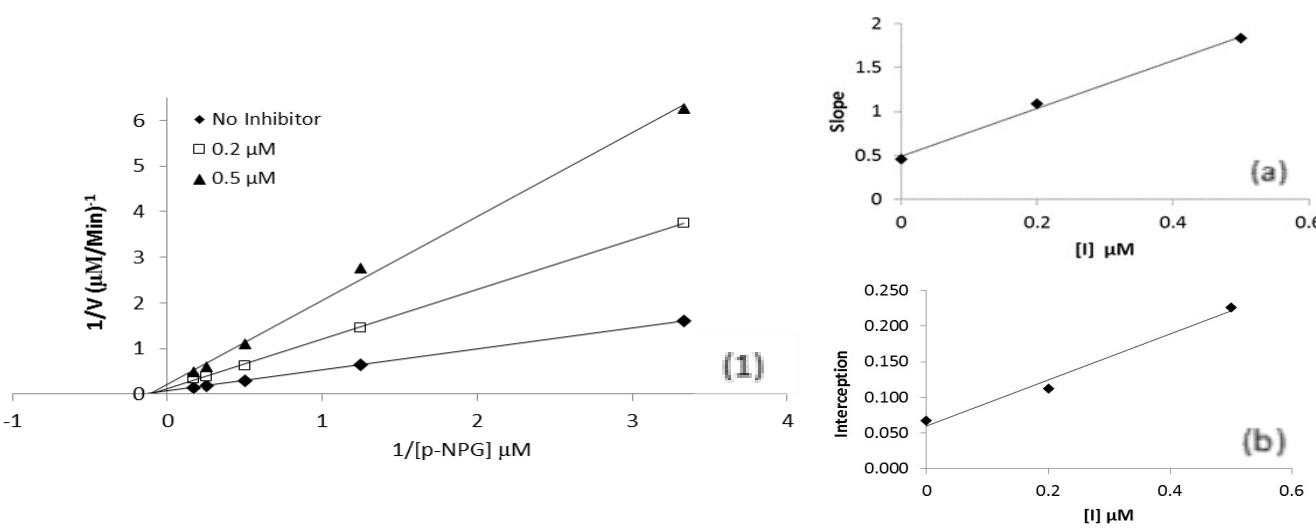

Fig.-2: Lineweaver-Burk Plot of 1 against $\alpha$-glucosidase (Baker's Yeast). Inset: Secondary Plot for Determination of $K_{i}(\mathrm{a})$, and Determination of $K_{i}^{\prime}(\mathrm{b})$
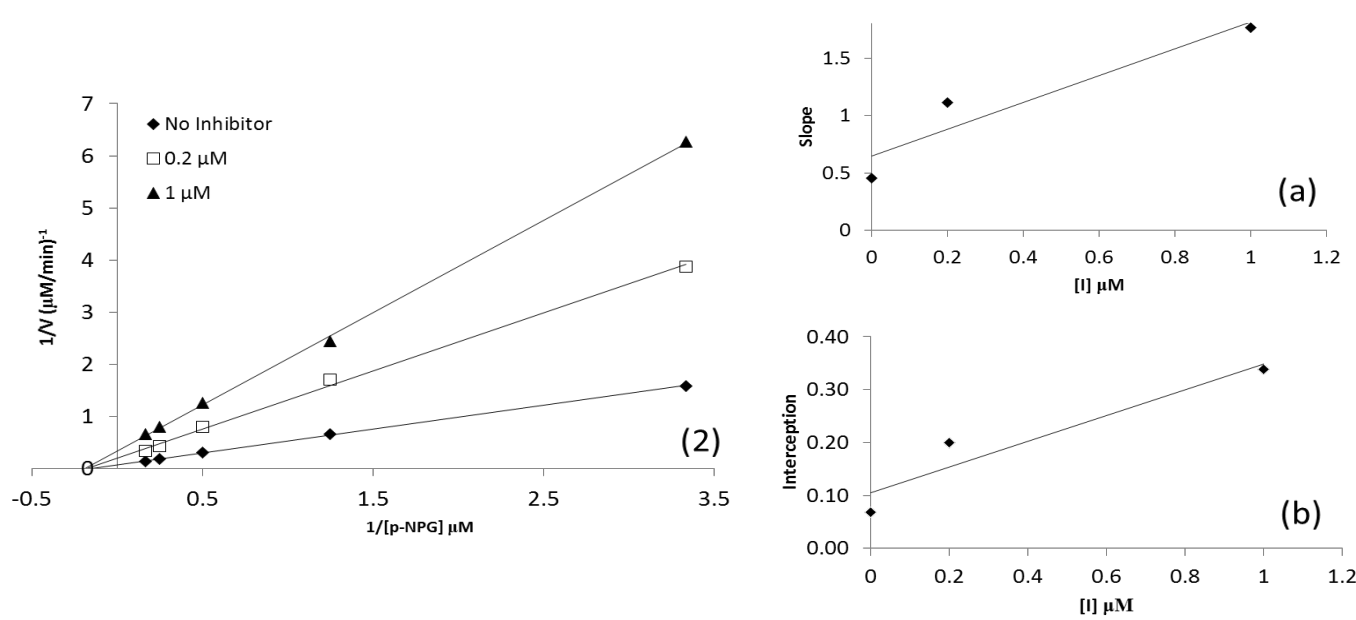

Fig.-3: Lineweaver-Burk Plot of 2 against $\alpha$-glucosidase (Baker's Yeast). Inset: Secondary Plot for Determination of $K_{i}(\mathrm{a})$, and Determination of $K_{i}^{\prime}(\mathrm{b})$
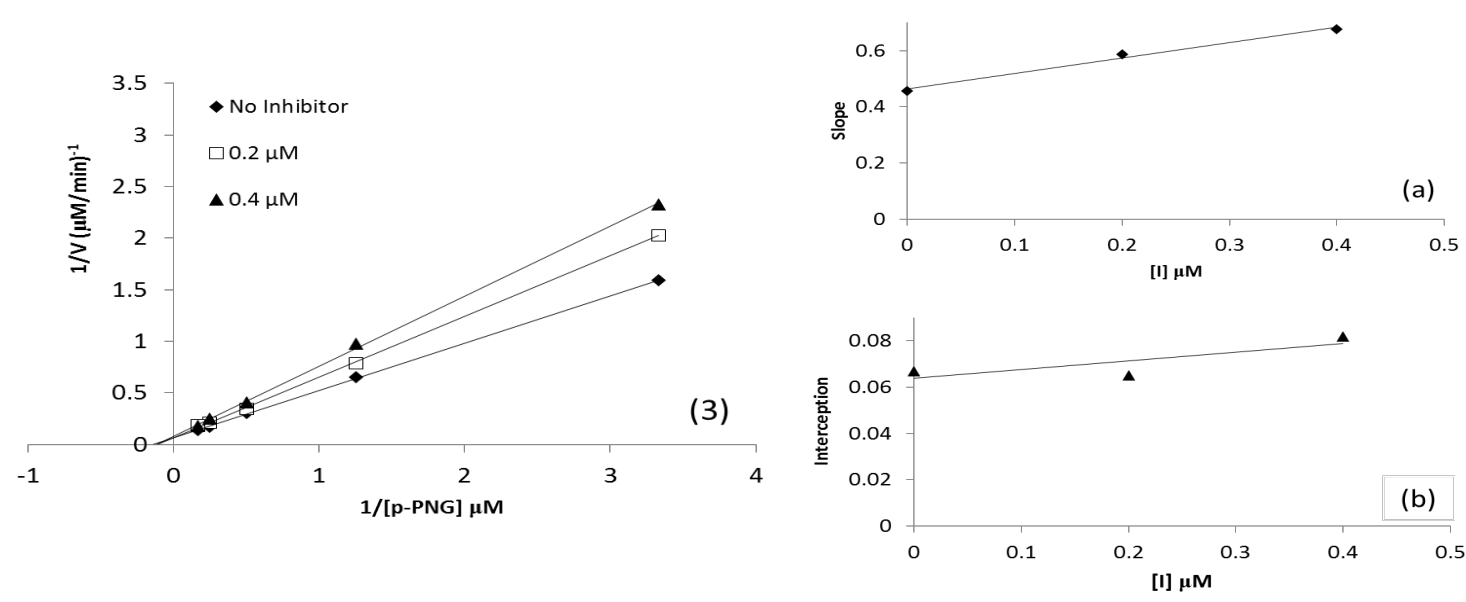

Fig.-4: Lineweaver-Burk plot of 3 against $\alpha$-glucosidase (Baker's Yeast). Inset: Secondary Plot for Determination of $K_{i}(\mathrm{a})$, and Determination of $K_{i}^{\prime}(\mathrm{b})$ 
RASĀYAN J. Chem.

Vol. 13 | No. 3 |1727-1734| July - September | 2020

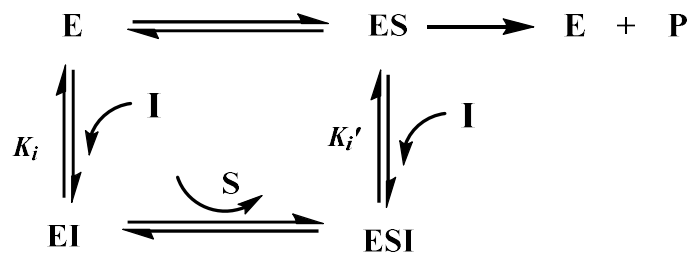

Fig.-5: Proposed Mechanism of Inhibition of 1-3 (I) against $\alpha$-glucosidase (Yeast). E (enzyme),S ( $p$-nitrophenyl- $\alpha$ D-glucopyranosid) and $\mathrm{P}$ (Glucose), respectively

Table-5: Kinetic Factors of 1-3 for Yeast $\alpha$-glucosidase

\begin{tabular}{c|c|c|c}
\hline \multirow{2}{*}{ Compounds } & \multicolumn{3}{|c}{ Yeast $\alpha$-glucosidase } \\
\cline { 2 - 4 } & $K_{i}(\mu \mathrm{M})$ & $K_{i}^{\prime}(\mu \mathrm{M})$ & Inhibition types \\
\hline $\mathbf{1}$ & 5.95 & 4.81 & noncompetitive \\
\hline $\mathbf{2}$ & 2.55 & 3.84 & noncompetitive \\
\hline $\mathbf{3}$ & 1.21 & 0.55 & noncompetitive \\
\hline
\end{tabular}

Our present results exhibited the strong enzymatic inhibitory against yeast $\alpha$-glucosidase in extracts of $C$. tagal and isolated compounds (1-3) than mammalian $\alpha$-glucosidase. This will favor that extracts of $C$. tagal and isolated compounds (1-3) can decrease blood sugar level.

\section{CONCLUSION}

In conclusion, we have conducted studies into the $\alpha$-glucosidase inhibitory activities and antioxidant properties of six selected East Kalimantan plants. The plants were selected based on ethnopharmacological knowledge and previous cultural use of the plants for diabetes therapy. We have determined that $C$. tagal extract [and in particular isolated compounds (1-3)] shows promise in diabetes therapy and prevention of the onset of diabetic complications, based on their potent antioxidant and $\alpha$ glucosidase inhibition activities. Also, mechanisms underlying the inhibition of isolated compounds (1-3) suggested that they could be used in combination with acarbose (antidiabetic drug). Moreover, a recent study has generally demonstrated that the strategy of combining ethnopharmacological knowledge with biological and chemical screenings can be highly effective in discovering previously unknown bioactive compounds.

\section{ACKNOWLEDGMENT}

We thank Dr. David Kreller for manuscript editing. R.R is thankful to the Faculty of Science Chulalongkorn University and the Ratchadaphiseksomphot Endowment Fund for a Postdoctoral Fellowship and a top-up for the foreign researcher, respectively. This research was financially supported by the Thailand Research Fund and a TRF-NSFC collaborative research grant (DBG5980001). Plant authentication was performed by Dr. Dwi Susanto at the Physiology Laboratory.

\section{REFERENCES}

1. R. R. O. Andrade, S. G. Jiménez, P. C. España, G. R. Ávila, V. R. Mollina, E. S. Soto, Journal of Ethnopharmacology, 109, 48(2007), DOI: 10.1016/j.jep.2006.07.002

2. O.O. Olaokun, A. E. Alaba, K. Ligege, N. M. Mkolo, South African Journal of Botany, 128, 319(2020), DOI: 10.1016/j.sajb.2019.11.030

3. K. Swarnalatha, C. H. V. K. Babu, B. H. Babu, Rasayan Journal of Chemistry, 12(2), 907(2019), DOI: $10.31788 / R J C .2019 .1225168$

4. X. Yao, L. Zhu, Y. Chen, J. Tian, Y. Wang, Food Chemistry, 139, 59(2013), DOI: 10.1016/j.foodchem.2012.12.045

5. L. Mojica, M. Berhow, E. Gonzales de Mejia, Food Chemistry, 229, 628(2017), DOI: 10.1016/j.foodchem.2017.02.124

6. S. Shobana, Y. N. Sreerama, N. G. Malleshi, Food Chemistry, 115, 1268(2009), DOI: 10.1016/j.foodchem.2009.01.04 
RASĀYAN J. Chem.

Vol. 13 | No. 3 |1727-1734| July - September | 2020

7. X. Liu, L. Zu, X. Zhou, L. Xiao, X. Yang, B. Wang, BMC Complementary and Alternative Medicine, 14(12), 1(2014), DOI: $10.1186 / 1472-688214-12$

8. W. Aligita, S. Muhsinin, E. Susilawati, Dahlia, D. S. Pratiwi, D. Aprilliani, A. Artarini, I. K. Adnyana, Rasayan Journal of Chemistry, 12(1), 157(2019), DOI: 10.31788/RJC.2019.1215059

9. K. R. R. Rengasamy, M. A. Aderogba, S. O. Amoo, W. A. Stirk, J. V. Staden, Food Chemistry, 141, 1412(2013), DOI: 10.1016/j.foodchem.2013.04.019

10. K. Sidiyasa, Tree Diversity in the Rain Forest of Kalimantan. In The Balance Between Biodiversity Conservation and Suistainable Use of Tropical Rain Forest, The Tropenbos Foundation, Wageningen, Netherland, p. 69,77(2001).

11. I. W. Kusuma, Murdiyanto, E. T. Arung, Syafrizal, Y. Kim, Food Science and Human Wellness, 3(3), 191(2014), DOI: $10.1016 /$ j.fshw.2014.12.004

12. S. Crevello, Journal of Human Ecology, 16(1), 69(2004), DOI:10.1080/09709274.2004.11905718

13. E. Mulyoutami, R. Rismawan, L. Joshi, Forest Ecology and Management, 257(10), 2054(2009), DOI: $10.1016 /$ j.forestco.2009.01.042

14. M. Leonti, G. I. Stafford, M. C. Cero, S. Cabras, M. E. Castellanos, L. Casu, C. S. Weckerle, Journal of Ethnopharmacology, 198, 417(2017), DOI:10.1016/j.jep.2016.12.044

15. E. M. Kuntorini, L. H. Nugroho, Biodiversitas, 11(2), 102(2010), DOI:10.13057/biodiv/d1 10210

16. R. Ramadhan, W. Worawalai, P. Phuwapraisirisan, Natural Product Research, 33(20), 2917(2019), DOI: $10.1080 / 14786419.2018 .1510395$

17. R. Ramadhan, I. W. Kusuma, R. Amirta, W. Worawalai, P. Phuwapraisirisan, Natural Product Research, 32(22), 2676(2018), DOI: 10.1080/14786419.2017.1378204

18. P. Prieto, M. Pineda, M. Aguilar, Analytical Bioechemistry, 269(2), 337(199), DOI:10.1006/abio.1999.4019

19. S. K. Das, L. Samanta, H. Thatoi, Journal of Herbs, Spices \& Medicinal Plants, 22(2), 105(2016), DOI: $10.1080 / 10496475.2015 .1057352$

20. H. N. Murthy, V. V. Herlekar, K. S. Joseph, S. Payamelle, S. Shinde, Journal of Herbs, Spices \& Medicinal Plants, 24(2), 213(2018), DOI:10.1080/10496475.2018.1443188

21. G. Clarke, K. N. Ting, C. Wiart, J. Fry, Antioxidants, 2(1), 1(2013), DOI:10.3390/antiox2010001

22. M. Liu, S. Yang, L. Jin, D. Hu, Z. wu, S. Yang, Molecules, 17(5), 6156(2012), DOI: $10.3390 /$ molecules 17056156

23. T. Damsud, S. Adisakwattana, P. Phuwapraisirisan, Phytochemistry Letter, 6(3), 350(2013), DOI: 10.1016/j.phytol.2013.04.001

24. I. L. Lawag, A. M. Aguinaldo, S. Naheed, M. Mosihuzzaman, Journal of Ethnopharmacology, 144, 217(2012), DOI:10.1016/j.jep.2012.08.019

25. Sumaiyah, Masfria, A. Dalimunthe, Rasayan Journal of Chemistry, 11(2), 505(2018), DOI: 10.31788/RJC.2018.1122068

26. J. A. O. Olugbuyiro, A. S. Banwo, A. O. Adeyemi, O. S. Taiwo, O. A. Akintokun, Rasayan Journal of Chemistry, 11(2), 798(2018), DOI:10.31788/RJC.2018.1121823

27. R. Ramu, P. S. Shirahatti, F. Zameer, L. V. Ranganatha, M. N. Nagendra Prasad, South African Journal of Botany, 95, 54(2014), DOI:10.1016/j.sajb.2014.08.001

28. J. C. Chukwujekwu, K. R. R. Rengasamy, C. A. de Kock, P. J. Smith, L. P. Slatětínká, J. van Staden, Journal of Enzyme Inhibition and Medicinal Chemistry, 31(1), 63(2015), DOI: 10.3109/14756366.2014.1003927

29. M. N. Qaisar, M. Uzair, M. Imran, B. A. Chaudhary, S. N. Hussain, Tropical Journal of Pharmaceutical Research, 15(2), 319(2016), DOI:10.4314/tjpr.v15i2.14

[RJC-5559/2020] 